Andenaes, E., Time, B., Torp, O., Kvande, T., and Lohne, J. (2019). "Risk Management in Procurement of Blue-Gren Roofs - A Project Owner Perspective" In: Proc. 27th Annual Conference of the International. Group for Lean Construction (IGLC), Pasquire C. and Hamzeh F.R. (ed.), Dublin, Ireland, pp. 97-108 DOI: https://doi.org/10.24928/2019/0263. Available at: 〈www.iglc.net>.

\title{
RISK MANAGEMENT IN PROCUREMENT OF BLUE-GREEN ROOFS - A PROJECT OWNER PERSPECTIVE
}

\author{
Erlend Andenaes ${ }^{1}$, Berit Time ${ }^{2}$, Olav Torp ${ }^{3}$, Tore Kvande ${ }^{4}$ and Jardar Lohne ${ }^{5}$
}

\begin{abstract}
Blue-green roofs are vegetated roofs used for stormwater management purposes. With the roof serving several different purposes at the same time, the risk that any of its functions could be compromised needs to be addressed. Risks related to roof defects may present a threat to the long-term operation of a building, and could lead to waste by making defective products. This article presents an investigation to explore how the Norwegian building sector handles and manages this risk.

Tender documents for green roof construction projects in the Norway are examined. Technical documents are studied to chart how the projects manage risks related to the integrity of the roofs in the tender phase. Findings suggest that risk in relation to building physics is not systematically analysed and managed in design and procurement phase of the project. Contractors are given significant control of design elements in certain common contract strategies. Risk is effectively not being managed in the early phase, with much of the risk management given to the contractors. The project owner will yield little control over decisions whose outcomes will only manifest long after the warranty period expires.
\end{abstract}

\section{KEYWORDS}

Blue-green roofs, risk management, contract strategy

\section{INTRODUCTION}

Blue-green roofs are roof assemblies where plants and various substrates are used to store water temporarily, gradually releasing it once the roof's capacity is reached. As such, they function as a mitigation measure against flooding from intense rain events, by detaining or

1 Ph.D. candidate, Department of Civil and Environmental Engineering, Norwegian University of Science and Technology, Trondheim, Norway, +47 92684 110, erlend.andenas@ntnu.no

2 Head researcher, Department of Materials and Structures, SINTEF Building and infrastructure, Trondheim, Norway, +47 97072 083, berit.time@ sintef.no.

3 Associate Professor, Norwegian University of Science and Technology, Trondheim, Norway, +47934 22673 , olav.torp@ntnu.no.

4 Professor, Department of Civil and Environmental Engineering, Norwegian University of Science and Technology, Trondheim, Norway, +47 90255 434, tore.kvande@ntnu.no.

5 Research scientist, dr. art. Department of Civil and Environmental Engineering, Norwegian University of Science and Technology, Trondheim, Norway, +47 93444 930, jardar.lohne@ntnu.no 
delaying runoff from roofs. This frees up capacity in the drainage system to manage runoff from other impervious surfaces. Blue-green roofs differ from ordinary green roofs by being actively designed to deliver this stormwater management function.

In Norway, climate change is manifesting in the form of milder weather with increased precipitation(Hanssen-Bauer et al., 2015). A phenomenon of particular interest is an increased frequency of quick, intense showers, during which large amounts of precipitation fall within a short time span. The intensity of this rainfall can lead to a higher level of surface runoff than can be managed with existing drainage systems or ground infiltration, with the excess water causing flooding. According to numbers from Finance Norway, payouts for weather-related damages have more than doubled in the last ten years (Hauge et al., 2017). As such, there is a growing push towards climate adaptation.

\section{Politics, STATE OF The NATION.}

The condition of stormwater pipes in Norway is far below par. The investment required to bring the existing wastewater and stormwater grids up to a good condition is expected to be around NOK 110 billion (RIF, 2015). The prohibitive cost of refurbishing the underground infrastructure, even without accounting for the cost of capacity upgrades, means that future climate challenges will primarily have to be addressed by on-site solutions including local retention and infiltration.

In densely developed urban locations, little space is left for green spaces on the ground level. Impermeable roads or buildings will cover most of the land surface. Blue-green roofs provide retention and detention capacity for stormwater, which would otherwise be hard to achieve without tying up highly contested ground space or excavating underground detention reservoirs at high costs (Johannessen et al., 2017).

However, adopting an active stormwater measure such as a blue-green roof on a building will imply a change in physical and operational conditions. Perhaps most notably, the literal burial of the roof membrane makes it much more difficult to detect damages or leakages. Additionally, moisture and temperature conditions at the roof membrane will change drastically. A roof with living vegetation will also require more intensive maintenance than conventional flat roofs. These aspects, and others, add risk elements to blue-green roof design compared to that of conventional roofs. Lean Construction includes focus on Transformation, Flow and Value (Koskela 1992). The main focus is on reducing waste, which comes in many categories. For example, Taiichi Ohno's seven wastes: overproduction, waiting, transportation, processing, inventory, movement, making defective products (Ohno 1988). Different categories of waste are relevant to the production of blue-green roofs. In this paper, risks for damages related to blue-green roofs are considered. This primarily relates to the seventh category of waste, making defective products. Reduced risk for damages will also increase the costumer value, thus supporting the principles in Lean Construction.

While blue-green roofs are adopted as a risk-reducing measure from the perspective of stormwater management, in other circumstances it adds to the overall risk picture. It is vital to determine the balance point between reduced and increased risk to assess the overall efficacy of blue-green roofs. Damages to the roof pose a threat to the long term operation and thereby to the life cycle costs of the building. 
This article aims to investigate how risk related to the building's quality is handled in practice, by examining documents from the design and procurement phase of construction projects featuring green roofs. The following research questions are examined:

What are the challenges and risks related to green and blue-green roofs?

What strategies are applied by project owners to control and manage risk related to green roofs in the procurement phase?

What improvements can be made?

The research is performed as a document study. Tender documents from recent construction projects featuring green roofs in Norway are examined to study how project owners manage the known technical risks associated with green roofs in design and procurement phase. Due to the inherent complexity of construction projects and the many actors involved, it has been decided to focus only on this phase and only from the project owner's perspective to provide a deeper, if narrower, understanding of these challenges.

The study is mainly limited to public projects whose tender documents were freely accessible, as it is difficult to gather detailed documentation on such cases. However, these projects are considered representative for the Norwegian building sector as a whole. A detailed study is expected to uncover issues that are relevant for green roof projects in general.

\section{THEORY}

\section{GREEN ROOFS IN NORWAY}

Green roofs have been used in Norway for several centuries in the form of sod roofs, which provided insulation as well as weather protection. This roof type still sees use in a modernized form on buildings mimicking traditional architectural styles (Jim, 2017). Modern green roofs remain relatively uncommon in Norway, but have recently surged in popularity as a "green" feature in modern architecture. Blue-green roofs are still a novelty element, but some manufacturers already offer off-the-shelf blue-green roof solutions (Protan, 2019).

The most common form of green roof assembly is a lightweight sedum assembly mounted directly on top of a conventional, compact, flat roof, a so-called "extensive" green roof. "Intensive" green roofs are built to provide green outdoor spaces on rooftops, and can range from simple grassy lawns to landscaped parks with bushes and trees. Intensive green roofs require a much thicker and heavier green roof assembly, which makes them less commonly seen. A blue-green roof assembly will follow the same principles as ordinary green roofs, but have a higher capacity for water storage than what the plants need to survive. Note that all green roofs will inherently have some form of stormwater management properties, even if they are not designed with it in mind. The principal composition of a blue-green roof is shown in Figure 1.

Research published by Byggfakta (2018) estimates 17,000 new buildings to be built in Norway between 2018 and 2021, at a total cost of 3500 billion NOK. There exists a great potential for using roofs for stormwater management as well as providing outdoor space, but it is vital that risks are well understood before blue-green roofs are implemented on 
such a broad scale. If wrong strategies to handle risks are chosen, this could lead to waste for the project owner.

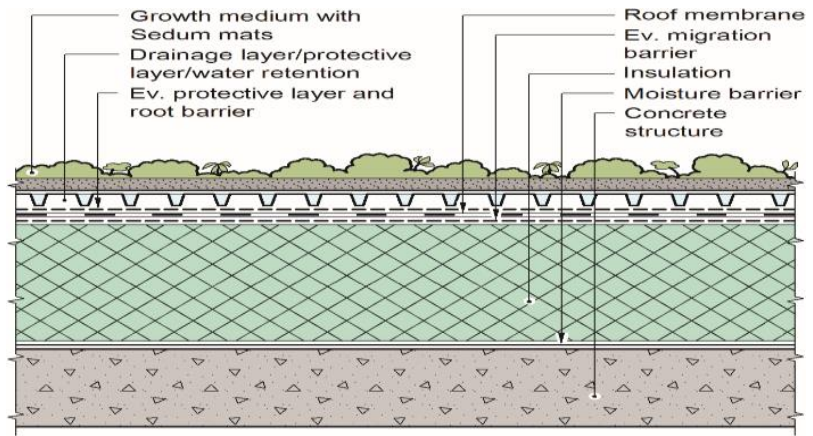

Figure 1: Composition of a green roof assembly on a compact, flat roof (Skjeldrum and Kvande, 2017).

\section{MAIN PROJECT DELIVERY MODELS IN A NORWEGIAN CONTEXT}

Several different contract strategies exist for construction projects, as outlined by Lædre (2009), from separation based to integration based approaches. The most commonly used in Norway are integration based approach like design build contracts and separation based approaches like design bid build. Strategies with Early Contractor Involvement are more and more applied.

In design build contracts, the project owner typically is responsible for the work until detail design, and then orders delivery from the contractor, essentially placing both detail design and build in the contractor's hands. The Norwegian rules for design build contracts are outlined in the standard NS 8407:2011. In design bid build contracts, the project owner has the responsibility for all the design and the construction, where suppliers are contracted individually.

The project owner of a construction project usually ends up owning and managing the building, and is thereby also responsible for facility management and life cycle costs. Private Public Partnership contracts transfer responsibility for financing, design, build and operation of the facility for a time period to the contractor (Lædre 2009).

\section{RISK AND UNCERTAINTY}

Uncertainty is an event that if it occurs, has a positive (potential upsides or opportunities) or negative (potential downsides or risks) effect on a project's objectives(Torp et al., 2018). Uncertainty management processes aim to reduce the risks and exploit the opportunities (Hillson, 2003). Risk is generally understood as a combination of the probabilities of unwanted events and their consequences, with some definitions following variations of "the likelihood and consequences of unintended outcomes" (Johansen, 2015). Several types of risk exist on several different analytic levels: The conceptual level, the processual level and the technical level. Uncertainty and hereby risk management addresses all types of uncertainty and risk, including risk related to cost, time, quality, scope, safety, customer satisfaction, company reputation, etc. (Torp et al. 2018). According to Torp et al. (2018), uncertainty management includes both proactive, interactive and reactive ways of thinking. Proactive uncertainty management is about analysing the uncertainty upfront to make 
actions before things happens. Interactive uncertainty management is about being able to handle things as they happen. Reactive uncertainty management is about understanding things that have happened, it is about repairing, exploiting opportunities and gathering experiences for future learning.

In the context of the construction industry, risk management commonly refers to the management of uncertainties related to processual matters, i.e. delivering the project within time and budget constraints (Lichtenberg, 2000). The health and safety aspects of risk are also fundamental and given much consideration in construction projects. However, the risk of compromising the quality, function and integrity of building components appears little studied. This article will attempt to dissect these technical risks rather than those that exclusively deal with costs, delays, or safety.

Statistics from the Norwegian building sector suggests that defects and leakages are common on flat roofs (Engeb $\varnothing$ et al., 2018), creating an issue of waste for project owners. The introduction of blue-green roof assemblies (in the form of additional layers on top of the existing roof structure) is not believed to cause more leakages, but leakages in a green roof will be much more difficult to detect and more expensive to repair as the roof membrane is covered.

To achieve a detail level suitable for a short article, a narrowing of the scope is required, concerning both the project timeline and the actors involved. Mainly, this article focuses on the building design and procurement phase, where the building is planned and designed. The final performance and quality of the blue-green roof will depend greatly on choices made in this phase. The consequences of such choices may only become apparent several years into the roof's lifetime, beyond the time of involvement by many actors in the project. As such, quality risk will largely be carried by the project owner, hence the focus on the project owner role in this article.

\section{COMMON FAILURE MODES OF BLUE-GREEN ROOFS}

The first research question asked in this paper is covering what challenges and risks that are related to blue-green roofs. The main forms of quality risk for green roofs are well known, and they are considered applicable for blue-green roofs as well. SINTEF Byggforsk (2013) lists technical recommendations and design flaws to avoid with green roofs. Additionally, most known risks concerning compact flat roofs tend to apply to green roofs as well, as they are usually mounted on a compact flat roof assembly. The main risk event is that of water leakage, which may compromise the integrity and functionality of the roof. Norwegian technical regulations stipulate that water intrusions should be avoided on all buildings (DiBK, 2017). Additionally, because of the living plants on the roof, poorly designed drains may be clogged with plant material, compromising the drainage function of the roof. The main critical points of vulnerability on blue-green roofs are schematically illustrated in Figure 2. 


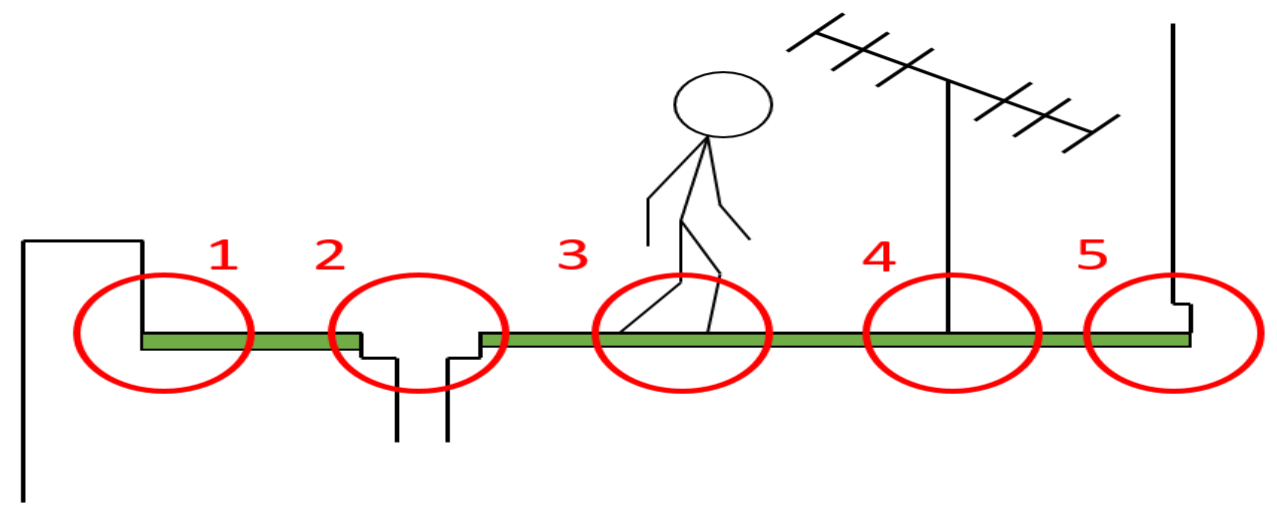

Figure 2: Critical vulnerable points of a green roof (also applicable for blue-green roofs): 1) Transitions between the roof and parapets. 2) Drains. 3) Traffic or work on the roof, including the use of tools such as landscaping tools or ladders. 4) Fastening points for technical equipment that perforates the roofing membrane. 5) Transitions between the roof and walls, particularly around doors.

\section{KNOWLEDGE GAP}

While failure modes and risk elements for green roofs are well known in theory, there exists a knowledge gap concerning how these risk elements are managed in practice. This relates to reducing waste related to making defective products (Ohno 1988). While building planners are generally aware of the vulnerable points of a roof structure, and strive to account for them when designing, there does not exist a framework defining how this risk is to be managed in the building process. The strategies of risk management will therefore vary between projects, depending on the companies or even the individual persons who author the building technical assessment reports in the pre-design phase. The strategies should include both proactive, interactive and reactive approaches (Torp et al. 2018). According to Hillson (2004) different strategies could be applied to handle uncertainty. Main strategies will be to avoid, reduce, share and accept risks and to share, exploit, accept and enhance opportunities. In relation to blue-green roofs, only risks are looked into. Then strategies to look into should be to avoid, reduce, share and accept risks related to bluegreen roofs.

\section{METHOD}

Various actors in the public sectors were approached to provide data from the design and procurement phase of green roof projects built in the past few years. Respondents were asked to provide documents relevant to the design of the green roof, as well as give some context around the decision to build green roofs in the first place. Unfortunately, responses were only returned concerning three construction projects, for two of which technical documents were provided.

Additionally, some data was found at the Norwegian national notification database for public procurement (Doffin, 2019). Searches were performed in Norwegian using the key 
words "green roof", "roof garden" and "sedum roof". This yielded a further four results, two of which had technical documents available.

The project tender documents were examined with a focus on mentions of the green roof, including the stormwater management plan. Any recommendations or requirements were noted. This includes the overall assembly of the roof as well as any mentions of riskreducing measures.

Where technical documents were available, they were examined in detail for mentions of the green roof. In particular, the pre-design reports and building physics notes contained information on the roof, showing what level of detail planning had been conducted before the tender was published.

\section{RESULTS}

Five main categories of risk have been identified as relevant to blue-green roofs.

1. Economical risk - covers matters of project cost, life cycle cost, and hereunder risks of delays in the construction process.

Health and safety risk - covers the physical safety and well-being of personnel on site, under all phases of the roof's lifetime.

Environmental risk - covers matters of pollution and emissions, to air, soil and water as well as to organisms.

Process risk - covers the achievement of specific project goals and the fulfilment of general success criteria, i.e. those outlined by Samset (2001).

Quality risk - covers the integrity, quality and function of roof components as well as that of the entire roof assembly, both at the point of hand-over and throughout the lifetime of the roof.

While there is some overlap between categories (for instance, risk scenarios in any category will be likely to have consequences in the form of economic losses), they are considered distinct enough to define the scope of the further work. This article will mainly disregard the first four categories in favour of examining quality risk in more detail.

The examined construction projects are summarized in Table 1. The scope of green roofs are shown, as well as the intentions of building them, if available. 
Table 1: General overview of examined projects.

\begin{tabular}{|c|c|c|c|c|c|c|}
\hline Project & $\begin{array}{l}\text { Type of } \\
\text { green roof }\end{array}$ & Intention & $\begin{array}{l}\text { Project } \\
\text { phase }^{1}\end{array}$ & $\begin{array}{l}\text { Contract } \\
\text { form }\end{array}$ & Project owner & $\begin{array}{r}\text { Technical } \\
\text { documents } \\
\text { available }\end{array}$ \\
\hline $\begin{array}{l}\text { Molde high } \\
\text { school } \\
(2014)\end{array}$ & $\begin{array}{l}\text { Roof } \\
\text { terrace }\end{array}$ & $\begin{array}{l}\text { Optional } \\
\text { greenery on } \\
\text { roof terrace }\end{array}$ & $\begin{array}{l}\text { Call for } \\
\text { turnkey } \\
\text { contracts }\end{array}$ & $\begin{array}{l}\text { Design } \\
\text { build }\end{array}$ & $\begin{array}{c}\text { Møre og Romsdal } \\
\text { county } \\
\text { administration }\end{array}$ & No \\
\hline $\begin{array}{c}\text { Nesbru } \\
\text { nursing } \\
\text { home }(2014\end{array}$ & $\begin{array}{l}\text { Sedum } \\
\text { roof } \\
\text { (extensive) }\end{array}$ & $\begin{array}{c}\text { Sedum roof } \\
\text { for } \\
\text { stormwater } \\
\text { management } \\
\text { and } \\
\text { aesthetics }\end{array}$ & $\begin{array}{l}\text { Call for } \\
\text { contracts }\end{array}$ & $\begin{array}{l}\text { General } \\
\text { contract }\end{array}$ & Asker municipality & No \\
\hline $\begin{array}{l}\text { Vækerøveien } \\
\text { municipal } \\
\text { housing } \\
(2015)\end{array}$ & $\begin{array}{l}\text { Sedum } \\
\text { roof } \\
\text { (extensive) }\end{array}$ & $\begin{array}{l}\text { Flat roof } \\
\text { mandated by } \\
\text { area plan, } \\
\text { Sedum } \\
\text { cover } \\
\text { chosen for } \\
\text { aesthetic } \\
\text { reasons. }\end{array}$ & $\begin{array}{c}\text { Call for } \\
\text { turnkey } \\
\text { contracts }\end{array}$ & $\begin{array}{l}\text { Design } \\
\text { build }\end{array}$ & Oslo municipality & Yes \\
\hline $\begin{array}{l}\text { Holmen } \\
\text { swimming } \\
\text { hall (2015) }\end{array}$ & $\begin{array}{l}\text { Roof lawn, } \\
\text { intensive } \\
\text { green roof }\end{array}$ & $\begin{array}{c}\text { Providing } \\
\text { outdoor } \\
\text { green space } \\
\text { on building } \\
\text { roof }\end{array}$ & $\begin{array}{l}\text { Pre- } \\
\text { project, } \\
\text { call for } \\
\text { build } \\
\text { contracts }\end{array}$ & $\begin{array}{l}\text { Build to } \\
\text { order }\end{array}$ & Asker municipality & Yes \\
\hline $\begin{array}{l}\text { Bjørlien } \\
\text { school } \\
(2016)\end{array}$ & $\begin{array}{l}\text { Sedum } \\
\text { roof } \\
\text { (extensive) }\end{array}$ & $\begin{array}{l}\text { Optional } \\
\text { sedum roof }\end{array}$ & $\begin{array}{c}\text { Call for } \\
\text { turnkey } \\
\text { contracts }\end{array}$ & $\begin{array}{l}\text { Design } \\
\text { build }\end{array}$ & $\begin{array}{c}\text { Vestby } \\
\text { municipality }\end{array}$ & Yes \\
\hline $\begin{array}{l}\text { Kannik } \\
\text { school } \\
(2016)\end{array}$ & $\begin{array}{l}\text { Sedum } \\
\text { roof } \\
\text { (extensive) }\end{array}$ & $\begin{array}{l}\text { Optional } \\
\text { sedum roof }\end{array}$ & $\begin{array}{l}\text { Call for } \\
\text { turnkey } \\
\text { contracts }\end{array}$ & $\begin{array}{l}\text { Design } \\
\text { build }\end{array}$ & $\begin{array}{l}\text { Stavanger } \\
\text { municipality }\end{array}$ & No \\
\hline $\begin{array}{l}\text { Nordvoll } \\
\text { school } \\
(2017)\end{array}$ & $\begin{array}{l}\text { Sedum } \\
\text { roof } \\
\text { (extensive) }\end{array}$ & Aesthetics & $\begin{array}{c}\text { Call for } \\
\text { turnkey } \\
\text { contracts }\end{array}$ & $\begin{array}{l}\text { Design } \\
\text { build }\end{array}$ & $\begin{array}{l}\text { Undervisningsbygg } \\
\text { (Oslo municipal } \\
\text { agency) }\end{array}$ & Yes \\
\hline
\end{tabular}

Table 2 examines the projects where documents are available in closer detail. Contract documents are examined for mentions of membrane tightness, specifications about the design of drains, and the detail level with which the roof assembly is described. Additionally, stormwater management plans are examined to investigate whether the project aims to take advantage of the stormwater management properties of the roofs. This property is often used to justify the construction of a green roof, but it rarely appears to be taken into account in practice. 
Table 2: Detailed specifications in project documents where those were available.

\begin{tabular}{|c|c|c|c|c|}
\hline Project & $\begin{array}{l}\text { Reference to } \\
\text { membrane } \\
\text { tightness }\end{array}$ & $\begin{array}{c}\text { Drain } \\
\text { specifications }\end{array}$ & $\begin{array}{c}\text { Assembly } \\
\text { specification in } \\
\text { tender/pre-design } \\
\text { documents }\end{array}$ & $\begin{array}{c}\text { Green roof } \\
\text { stormwater function }\end{array}$ \\
\hline $\begin{array}{l}\text { Vækerøveien } \\
\text { municipal } \\
\text { housing } \\
(2015)\end{array}$ & None & $\begin{array}{l}\text { Downpipes } \\
\text { specified, but } \\
\text { not drains }\end{array}$ & $\begin{array}{c}\text { Detailed } \\
\text { specification }\end{array}$ & $\begin{array}{l}\text { Not mentioned in } \\
\text { stormwater } \\
\text { management plan }\end{array}$ \\
\hline $\begin{array}{l}\text { Holmen } \\
\text { swimming } \\
\text { hall (2015) }\end{array}$ & None & $\begin{array}{l}\text { Drains shown } \\
\text { in drawings }\end{array}$ & $\begin{array}{c}\text { Detailed } \\
\text { specification of } \\
\text { entire roof assembly }\end{array}$ & $\begin{array}{l}\text { Not mentioned in } \\
\text { stormwater } \\
\text { management plan }\end{array}$ \\
\hline $\begin{array}{l}\text { Bjørlien } \\
\text { school } \\
\text { (2016) }\end{array}$ & $\begin{array}{l}\text { Integrity test } \\
\text { recommended }\end{array}$ & $\begin{array}{l}\text { Need for } \\
\text { inspection } \\
\quad \text { drain } \\
\text { highlighted }\end{array}$ & $\begin{array}{l}\text { Detailed } \\
\text { specification of roof } \\
\text { assembly }\end{array}$ & $\begin{array}{c}\text { No stormwater } \\
\text { management plan } \\
\text { available }\end{array}$ \\
\hline $\begin{array}{l}\text { Nordvoll } \\
\text { school } \\
\text { (2017) }\end{array}$ & $\begin{array}{l}\text { Specifications } \\
\text { given } \\
\text { No mention of } \\
\text { integrity test }\end{array}$ & $\begin{array}{l}\text { Need for } \\
\text { redundant } \\
\text { drain } \\
\text { highlighted }\end{array}$ & $\begin{array}{c}\text { No detailed } \\
\text { specification of } \\
\text { green roof assembly }\end{array}$ & $\begin{array}{l}\text { Not mentioned in } \\
\text { stormwater } \\
\text { management plan }\end{array}$ \\
\hline
\end{tabular}

In general, the matter of risk management does not appear to be treated in a consistent manner between the examined projects. For all of the projects listed in Table 2, a pre-design report lists some requirements and recommendations for the roof assembly. However, the level of detail in these reports varies. Some contain thorough assessments; others scarcely say more than "sedum mats will be put on the roof". References are sometimes made to the SINTEF Byggforsk design guides, but these guides do not necessarily cover special cases such as building transitions. The thoroughness of the pre-design reports appears to rest entirely on the person who wrote them; this will vary wildly in practice when there is no specific framework to follow. Where green roofs are only included as an optional addition to the project, only general functional requirements seem to be given.

\section{DISCUSSION}

This article seeks to answer the following research questions: What challenges can be identified related to green roofs, what strategies are taken by project owners to control and manage risk related to green roofs, and what improvements can be made. The last question relates to how to reduce waste related to making defective products when constructing green roofs.

From risk management, different strategies to manage risks are avoid, accept, share or transfer (Hillson 2004). There does not appear to be any consistency to the technical risk management related to roofs.

Design and build contracts give contractors much freedom to choose the roof concept and plan it in detail. This is a strategy where the project owner transfers the risk related to the roof design and construction to the contractor. When green roofs are made optional, it 
is completely up to the contractor to design the roof, with the owner choosing whether to implement it once a suggestion is presented. Here exists a possibility to avoid the risk related to green roofs, if the contractor chose to design another type of roof construction. The aspect of roof-related risk appears to be completely absent from the tender documents in these cases. In other types of contract strategies with Early Contractor Involvement and or alliancing, one could choose a strategy of sharing the risk related to green roofs, where the project and the contractor share the risk among them. With a PPP (private-public partnership) solution, responsibility for financing, design, construction and operating the facility for a time period (20-25 years) would also be transferred to the contractor. The strategy would then be to transfer all risks related to the roof construction to the private party, typically a contractor.

A suggested improvement includes the development of a more rigid framework used when procuring green roofs, choosing a strategy to avoid, share or transfer the risk. This could take the form of a checklist that covers the basic questions that should be asked and answered when a blue-green roof is to be procured. The framework could include an overview of the most commonly problematic roof details as well as requesting the contract participants to agree on a common strategy for managing building technical risk.

\section{CONCLUSION}

The relation between building physics/technical solutions and process-related issues seems to be little explored. The management of quality risk is not treated explicitly or consistently in risk management processes, nor in contract strategies. While processual risks is a field of study in itself, technical risks are not given the same level of systematic consideration in project risk management.

While available data is limited, possibly to the point of insufficiency, it can be seen that none of the examined projects explicitly manage technical risks in a systematic way. Common technical risks are covered better in some pre-design documents than in others, but this appears to vary depending on their authors. With pre-design documents lacking detail, it will be up to the contractor to pick a concept, which might not be as robust as desired from the project owner's perspective. It is up to the project owner to choose risk management strategy, either accept the risk, transfer the risk to the contractor, share the risk with the contractor or simply avoid the risk, by choosing an alternative roof construction.

\section{FUTURE WORK}

Work will continue on this subject, broadening the scope to look at the perspective of other actors and other phases of the building process. The risk category of process risk will also be investigated, focusing on the choice of green roof concept as opposed to the execution of a given concept. Finally, it will be sought to develop guidelines for managing technical risks related to green and blue-green roofs.

\section{ACKNOWLEDGEMENTS}

We would like to acknowledge and extend our gratitude to parties who for the moment will remain anonymous for the review process. 


\section{REFERENCES}

Byggfakta (2018) Tak og fasade, rapport 2018. April. Byggfakta. Available at: https://gratisdemo.byggfakta.no/svimlende-summer-pa-tak-og-fasade.

DiBK (2017) Byggteknisk forskrift (TEK17), §13-9. Available at: https://dibk.no/byggereglene/byggteknisk-forskrift-tek17/13/vi/13-9/ (accessed 25 February 2019).

Doffin (2019). Available at: https://www.doffin.no/en (accessed 6 March 2019).

Engebø A, Andenæs E, Kvande T, et al. (2018) Governing Flat-Roof Constructions: A Case Study. In: 26th Annual Conference of the International Group for Lean Construction, 2018, pp. 1079-1089. Available at: http://iglc.net/Papers/Details/1502 (accessed 8 March 2019).

Hanssen-Bauer I, Drange H, Førland EJ, et al. (2015) Klima i Norge 2100. Kunnskapsgrunnlag for klimatilpasning oppdatert i 2015.

Hauge ÅL, Flyen C, Almås AJ, et al. (2017) Klimatilpasning av bygninger og infrastruktur - samfunnsmessige barrierer og drivere. Klima 2050 Report 4-2017, 28 February. Trondheim, Norway: SINTEF Building and Infrastructure.

Hillson D (2003) Effective Opportunity Management for Projects. Marcel Dekker New York.

Jim CY (2017) An archaeological and historical exploration of the origins of green roofs. Urban Forestry \& Urban Greening 27: 32-42.

Johannessen BG, Hanslin HM and Muthanna TM (2017) Green roof performance potential in cold and wet regions. Ecological Engineering 106: 436-447.

Johansen A (2015) Project Uncertainty Management: A New Approach-The 'Lost Opportunities' Practical uncertainty management seen from a project joint perspective.

Koskela L. (1992) Application of the new production philosophy to Construction. CIFE Technical report \#72, September 1992, Stanford University.

Lædre O (2009) Kontraktstrategi for bygg- og anleggsprosjekter. Bergen, Norway: Fagbokforlaget.

Lichtenberg S (2000) Proactive Management of Uncertainty Using the Successive Principle: A Practical Way to Manage Opportunities and Risks. Polyteknisk Press.

Ohno Taiichi. (1988). Toyota production system. Productivity Press, Cambridge, MA. 143 p.

Protan (2019) Mer enn bare et tak - Protan. Available at: https://www.protan.no/bluegreenroof/ (accessed 25 January 2019).

RIF (2015) Norges Tilstand 2015. Available at: https://www.rif.no/wpcontent/uploads/2018/05/rif_stateofthenation_2015_lavopploeselig.pdf (accessed 31 January 2019).

Samset K (2001) Prosjektvurdering i Tidligfasen: Fokus På Konseptet. Tapir forlag.

SINTEF Byggforsk (2013) Byggforskserien 544.823 Sedumtak. SINTEF Byggforsk.

Skjeldrum PM and Kvande T (2017) Moisture-resilient upgrading to blue-green roofs. Energy Procedia 132: 417-422.

Torp O, Bølviken T, Aslesen S, et al. (2018) Is integration of Uncertainty Management and The Last Planner System a good idea? In: Proceedings of The 26th Annual Conference of the International Group for Lean Construction, 2018 
Fürstenberg, D., and Lædre, O. (2019). “Application of BIM Design Manuals: A Case Study.” In: Proc. $27^{\text {th }}$ Annual Conference of the International. Group for Lean Construction (IGLC), Pasquire C. and Hamzeh F.R. (ed.), Dublin, Ireland, pp. xx-xx. DOI: https://doi.org/10.24928/2018/0147. Available at: 〈www.iglc.net>. 